\title{
Money Supply and Inflation in Vietnam: An Approach from Structural Equation Model
}

\author{
Thu Tran Thi Hoai \\ School of Economics, Shanghai University, 99 Shangda Road, Shanghai 201900, China
}

\begin{abstract}
This paper examines the relationship between money supply and inflation in Vietnam. Basing on the operating mechanism of the mediator - money transmission channels, Structural Equation Model (SEM) is being applied to describe and explain the uninterrupted impact chain from money supply to transmission channels and then from transmission channels to inflation in Vietnam. Data are collected from World Bank statistics as well as the General Statistics Office of Vietnam in the time period of 1995 to 2016 quarterly, to generate ad estimate the weight of the causal effects. The experimental result of this analysis shows that interest rate and exchange rate are the two main channels to secure the controlling purpose of money supply on inflation in Vietnam.
\end{abstract}

Keywords: inflation, money supply, money transmission channels, monetary policy, credit, exchange rate

DOI: $10.7176 / \mathrm{JESD} / 10-10-10$

Publication date:May $31^{\text {st }} 2019$

\section{Introduction}

Inflation is a popular macroeconomic phenomenon having great impacts on a wide range of economic and social aspects. These impacts can be both positive and negative depending on the capability of adjusting to fluctuations and the foreseeable level about inflation rate. High inflation rate results in dramatic changes in the price of inputs and outputs, which leads to instability in producing process. Inflation also encourages the process of speculative hoarding and therefore causes disorders in the operation of banking system. If inflation is predictable, the negative impacts, hence, will be limited; on the other hand, inflation rate goes beyond the control means the incorrect investing decisions and ineffective economic resources allocation will be made.

Monetary policy has been so far become an efficient instrument being used by Government to interfere the state economy with a view to stabilizing macro economy and controlling market price. In the whole process of operating the state economy, monetary policy affects almost all economic fields in general and especially the financial market. The final purposes of monetary policy are economic output, price and employment (Miller \& Vanhoose, 2004). In short-run, through the monetary criteria such as M2, credit, interest rate and exchange rate, the operation of money supply will be supported to attain these final purposes.

Inflation being restrained at the suitable level with the growth of economy is one of the main objectives of monetary policy. With the interfering instruments and through transmission channels, inflation rate will be kept under control at the level that supports developing tendency and purpose of monetary policy. Using structural equation model, this paper examines the impact of monetary policy on inflation criteria in Vietnam through transmission channels. Basing on the analyzing results, recommendations of developing and improving the effectiveness and efficiency of monetary policy regarding inflation purpose will be stated.

\section{General Researching Field}

2.1. The main determinants of inflation in Vietnam

Researches about the determinants of inflation recently have mentioned consumer price index (CPI), money supply, interest rate, exchange rate, world oil and rice price, etc. IMF's researches (2003) analyzed the role of money supply in inflation using Structural Vector Autoregressive Modeling to show that the internal operation is the most important factor explaining the fluctuation of inflation, and therefore implied the recommendation of using money supply to attain inflation purpose. IMF (2006), more specifically, examined the role of monetary policy on inflation in Vietnam. The result of analysis showed that the increasing speed of money supply and credit had been in correlation since 2002. The expected inflation rate and the number of economic output have impacts on inflation, meanwhile oil price shock and exchange rate hold very little portion in explaining the fluctuation during researching time period. Moreover, Vietnam normally experienced a longer time of inflation than the other countries in region, therefore the higher the expectation of people on inflation, the more difficult it will be to control inflation.

It can be said that the determinants of inflation in Vietnam focus mainly on some primary factors. Camen (2006) used, again , Structural Vector Autoregressive Modeling to generate the conclusion that the aggregate credit in the economy accounts for $25 \%$ of the fluctuation in consumer price index and is the main factor impacting inflation after 24 months, meanwhile M2 and interest rate account for a very small proportion in explanation (below 5\%). Researches carried out by Truong Van Phuoc and Chu Hoang Long (2005) with Granger causality approach had proved that the factors determining inflation during 1994-2004 in Vietnam are the previous inflation 
rates and output. Money supply, according to these scholars' analysis, as well as the world oil price, rice price and exchange rate, had very little or even no meaning in the fluctuation of inflation. Le Viet Hung \& Pfau (2008) examined the operating mechanism of Vietnamese monetary policy from 1996 to 2005 to imply that there did have the rigid relationship between money supply and the real output, however the connection between money supply and inflation was not really obvious. Pham The Anh (2009)'s analysis with the time period from 1998 to 2008 and the emphasis on the following factors at the same time: CPI, money supply, interest rate, exchange rate, industry output. One of the vital implications was the role of increasing speed in money supply on inflation (after 3 periods) meanwhile interest rate acted in a passive way. The same experimental results can be found in other researches (Nguyen Thuy Vinh \& Fujita, 2007; UNDP, 2008).

\subsection{Money Transmission Channels}

Monetary supply is operating through the instruments system and the adjustment in these instruments makes M2 fluctuate. Then, the changes in money supply affect the inflation purpose of monetary policy. According to Miller \& Vanhoose (2004), monetary policy of a certain country has three final purposeswhich are economic output, inflation and employment. The instruments of monetary policy are used in order to flexibly adjust money supply and therefore attain the objectives of a certain decision. To attain the final objective of controlling inflation, monetary policy does the job through the mediating objectives or transmission channels. Apart from the traditional transmission channel which is interest rate according to Keynes Mishkin (2004), the other channel can be mentioned such as: aggregate credit, aggregate asset and exchange rate. This process is illustrated in figure 1.

The final purpose of monetary policy is to attain federal targets which are employment, output, price level or inflation. However, the Central Bank is incapable of achieving this purpose directly through the instrument system of monetary policy. Using the transmission channels and the explanatory variables providing the current and expected information of the economy, Central Bank, in the end of the day, can complete this task.

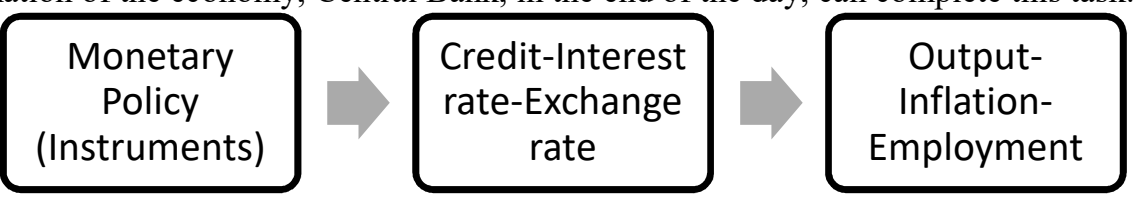

Figure 1: Transmission Channels of Monetary Policy

\subsection{Structural Equation Model}

Structural Equation Model is used to analyze a complex causal relationship. This can be considered as an expansion of general linear model which allows to estimate and testify simultaneously a number of regressive equations. Moreover, SEM also helps to estimate simultaneously a number of equations with different dependent variables in a single chain of causal relationships. As far as we have discussed, transmission channels act as a mediation between money supply and its final objectives, therefore SEM completely can be applied in this case to examine the impact of monetary policy on the subsequent factors.

Structural Equation Model is used widely in various fields such as administration, business, sociology, psychology (Pham Duc Ky, 2015). Structural equation models are not necessarily a linear function, hence this approach can be seen as a general model and applied in behavioral science research. It is said that SEM is the combination of factor analysis and regression analysis or can be known under the name path analysis.

\section{The Relationship Between Money Supply And Inflation In Vietnam}

\subsection{The recent evolution of inflation in Vietnam}

The evolution in policy manipulating Vietnamese economy has so far attained dramatic developments and achievements such as: the economic growth rate has experienced a relatively high level ( $7 \%$ since revolution period) whereas the poverty ratio has been decreasing, living standard has been improved much higher in comparison with 30 years ago and Vietnam has been considered as a country with medium income level. However, the real world situation shows us that Vietnamese economy is still facing a lot of difficulties such as the chronic inflation, the trade deficit condition as well as the high government debt and federal debt. One of the most considerable troubles faced by Vietnam economy is that the work of controlling inflation is not really effective and efficient. This situation leads to a subsequent practice that monetary policy should be operated in a proper way that is able to both encourage economic growth and put inflation under control at the same time. During 2005-2014, the financial crisis and world economic depression had affected considerably the economy of Vietnam, making inflation of the country really unstable and out of control in comparison with the others in area. Figure 2 showing the inflation evolution of Vietnam and the other ASEAN countries is provided below for illustrating this practice. The tendency of changes relates to money supply and credit during this period. 


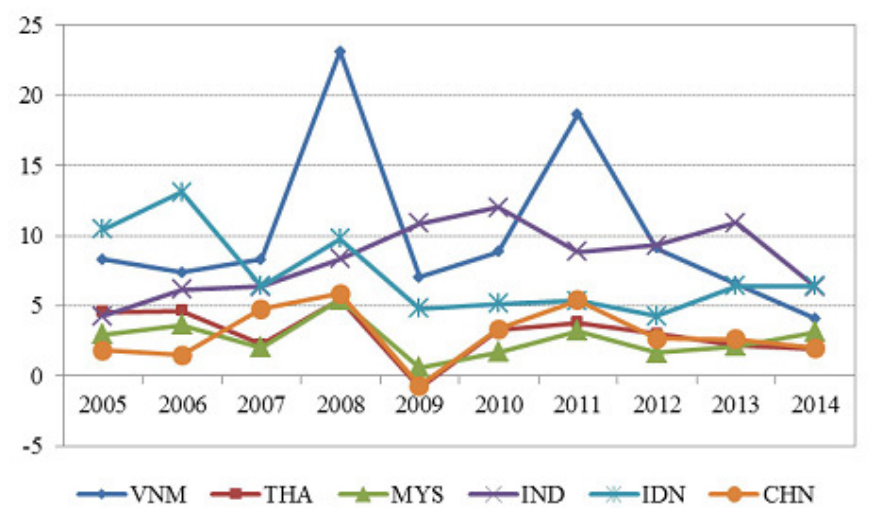

Figure 2: The Evolution of Inflation in Vietnam and ASEAN countries 2005- 2014

Source: World Development Indicator, 2014

Figure 2 helps to find out that inflation in Vietnam has been always higher than the other ASEAN countries' recently. Moreover, it also helps to generate an implication that inflation in Vietnam has a cyclical characteristic, which is clarified by the fact that inflation rate experienced a sudden increase every two years. Since 2012, inflation rate seems to decrease and maintain at a relatively low level. Researches and application in monetary policy are definitely needed to achieve inflation purposes in the economic background of Vietnam nowadays.

\subsection{Monetary policy instrument and Inflation}

This part is about to describe the operating mechanism of monetary policy through transmission channels to affect onto inflation in Vietnam with the illustrating data collected from IMF and General statistic office of Vietnam.

3.2.1. Interest rate channel

The impact of changes in money supply onto inflation is firstly conveyed through interest rate. According to Keynes, when money supply increases, the interest rate will decrease, the aggregate output will increase and the general economic price, therefore will increase. Theoretically, nominal interest rate and inflation have a positive correlation, which means when inflation increases, the nominal interest rate will also increase to secure the real interest rate to be accepted by economic entities. The potential of real interest rate has the impact on expectation as well as consumption and investment activities. When managing to identify the expected inflation, if consumers believe that the saving interest rate will not change or increase very little, which means that the real interest rate will be negative, they have the tendency to withdraw the saving deposits and invest back into real estate market or security market to maintain purchasing power. This practice will consequently create bubble condition in the real estate market and make the CPI increase, hence, the real interest rate is a very important variable which directly affects the entities' consumption decision, investment decision in the economy as well as determines inflation expectation. Therefore, the Central Bank in countries usually controls inflation expectation using the real interest rate. Normally, the Central Bank will begin with increasing interest rate gradually when inflation approaches to nominal saving interest rate. That means, the Central Bank tends to maintain a positive real interest rate policy, which helps to limit the expectation of the market about negative real interest rate and increase asset price. Besides, the increase in official interest rate of Central Bank can have a great impact on deflation when:

- The fluctuation in official interest rate of Central Bank has a really fast and strong effect on the interest rate in the economy and exchange rate, especially in an open financial system market with really high level of competition. At this moment, most of the contracts will be agreed basing on a floating interest rate rather than a fixed one and therefore the effect of changes in official interest rate on Central Bank becomes stronger onto the other interest rates and exchange rate.

- Financial liability is at a higher level than GDP. This ratio will increase in the scenario of financial liberalization (on the other hand, financial liberalization also leads to increase financial asset. However, the real world situation in other developed countries has implied that the fact of removing volume control will cause the liabilities asset to increase rather than entities asset).

- For the countries or regions who have financial liabilities asset outnumbers financial entities asset, which is expressed in a negative rather than positive income. For instant, monetary tightening (or monetary contraction) in the case of net debt under floating interest rate of households is higher than that of the enterprises will have a greater impact on price fall of retail goods than the investment goods. In contrast, if the net debt under floating interest rate of households is lower than that of enterprises, monetary contraction hence will affect less on the price fall of retail goods than investment goods.

However, during the last period, both interest rate for deposits and loans have no rigid relationship with money supply due to the interest rate operating mechanism of Central Bank. This result is illustrated in figure 3 . Analysis on the impact of interest rate transmission channel onto CPI is expressed in figure 3 (right side) showing 
that there does have a relationship between these two variables, the result of which will be testified through SEM in the coming part.
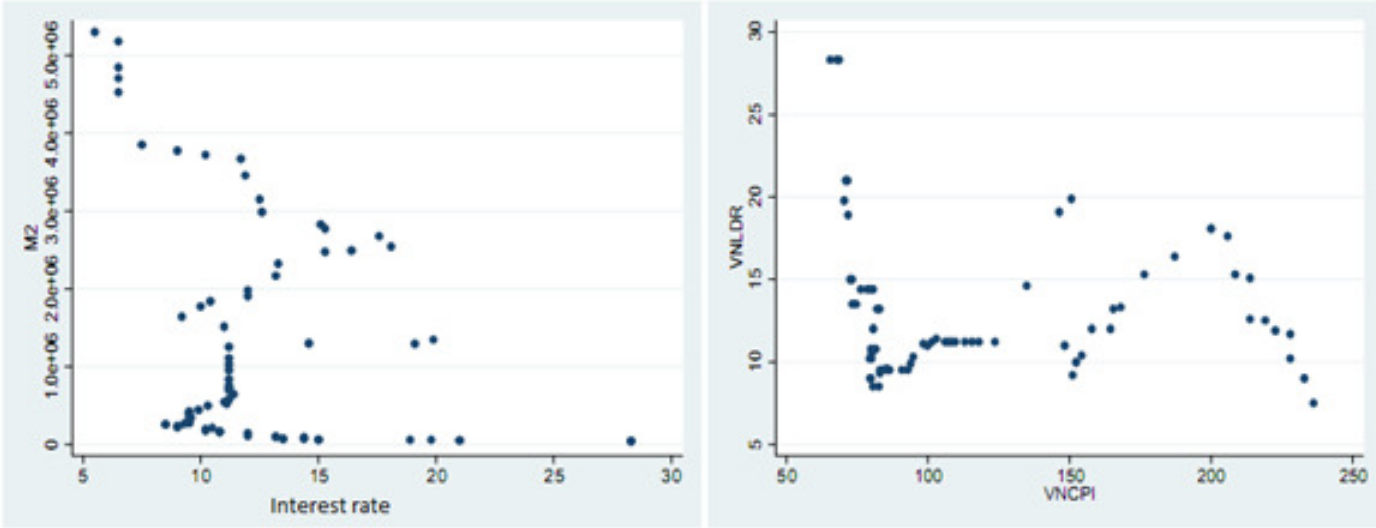

Figure 3: M2-Interest rate; Interest rate-CPI regression plot diagram

\subsubsection{Exchange rate channel}

The impact of the monetary policy on inflation is also conveyed through exchange rate channel. In fact, if the interbank average exchange rate USD/VND increases, the inflation will consequently increase. When money supply increases, interest rate will decrease and aggregate demand will also increase, which will push the general price to a higher level. This practice also makes exchange rate increase. The real evolution of money supply and exchange rate between the US currency and Vietnamese currency has experienced a dramatic increase since 1990 until now. This relationship has been found both theoretically and experimentally in Vietnam.

The analyzing result indicates a positive correlation between exchange rate and CPI. When exchange rate increases, inflation will be pushed higher. The experimental result will be testified in coming part.
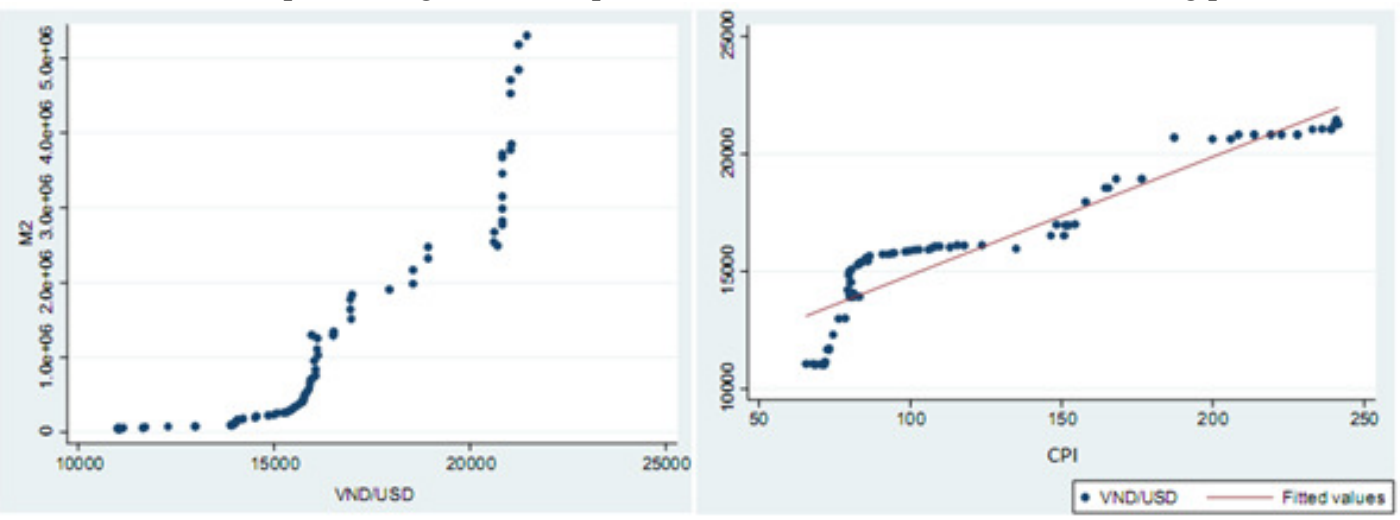

Figure 4: M2-Exchange rate; Exchange rate-CPI regression plot diagram

\subsubsection{Asset Price Channel}

Although security market has just operated for more than 10 years until now but it has been doing really well with the transmission role with a view to the final purposes of the economy. Asset Price Channel conveys the effect of monetary policy onto these final targets through the following mechanism: Theoretically, monetary expansion will lead to a decrease in the interest rate, which makes asset price increase as well as the expected income in the future of an entity holding these assets will also increase. Therefore, it will encourage consumers to expense more, invest more and as a result, demand in the security market increase at the same time with security price. As a whole, the transmission mechanism of monetary policy through asset price is working effectively under the economic condition of Vietnam. On the other hand, monetary expansion mandated through increasing money supply M2 or decreasing operating interest rate, stock price has a tendency of rising and therefore generate new demand of investment, increase aggregate demand and finally the general price of the economy.

3.2.4. Credit Channel

Monetary policy can affect inflation through Keynes operating mechanism. Credit channel played an important role in transmitting monetary policy of the Central Bank when interest rate channel and asset channel were used as transmission channels in capital market and exchange rate channel was not that effective because Vietnam used to pursue a relatively inflexible exchange rate mechanism. The fact that increasing speed of credit is high or low does influence the procedure of encouraging economic growth or inflation of the Central Bank. The increase in money supply means that interest rates tend to decrease and demand of investing and consuming increase, which leads to the reactions of banking system to increase lending loans. Once aggregate credit witnesses a speedy 
increase in such a short run, it will consequently put a pressure on general price level. The real situation of manipulating monetary policy in Vietnam can show obviously this practice.

Figure 5 illustrates the positive relationship between money supply M2 and aggregate credit in Vietnam. The ability and desire to extend credit of financial system fall owing to liabilities and bad debt has considerably increase meanwhile the risk controlling system is relatively weak. The level of transmitting activity through credit channel indicates that the effectiveness of monetary tightening has cut down the ability and desire to extend credit of financial system. The characteristic of stablizing capital structure, asset quality has a tendency of supporting the effect of monetary tightening to be long lasting and therefore generate certain risks such as unstabilities in financial system and devaluate the role of credit in the economy.
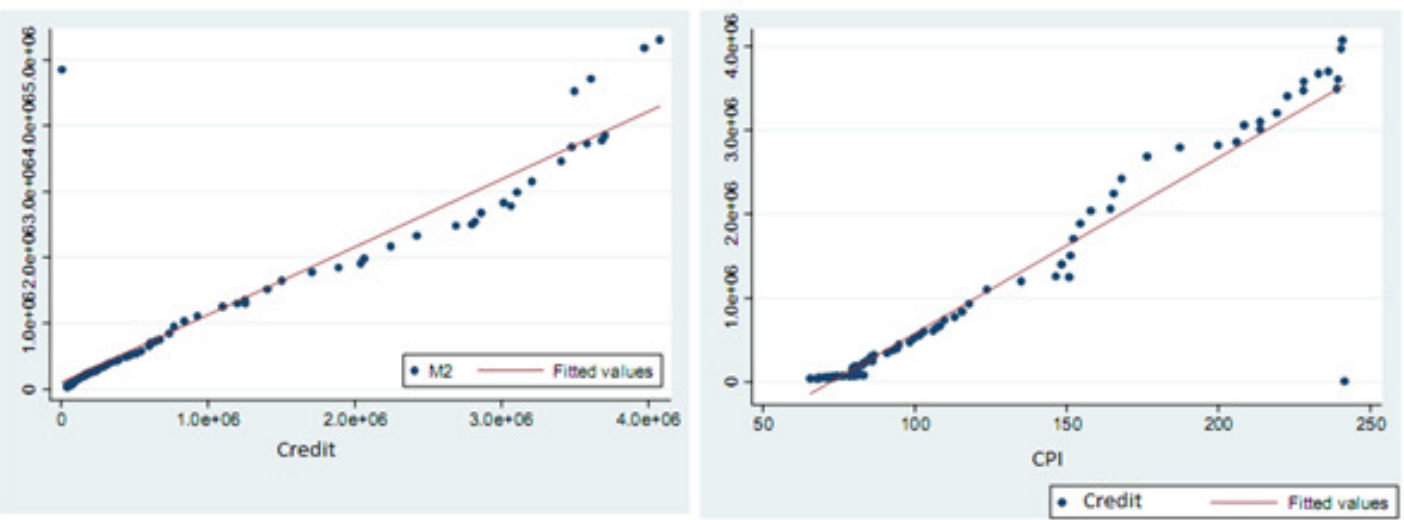

Figure 5: M2-Credit; Credit-CPI regression plot diagram

3.2.5. Monetary policy instruments and Inflation

Figure 6 illustrates the relationship between money supply and CPI of Vietnam from 1995 to 2015 quarterly. The result shows that when money supply increases, CPI will also increase and moreover the way of increasing in CPI is relatively similar to the way of increasing in money supply.

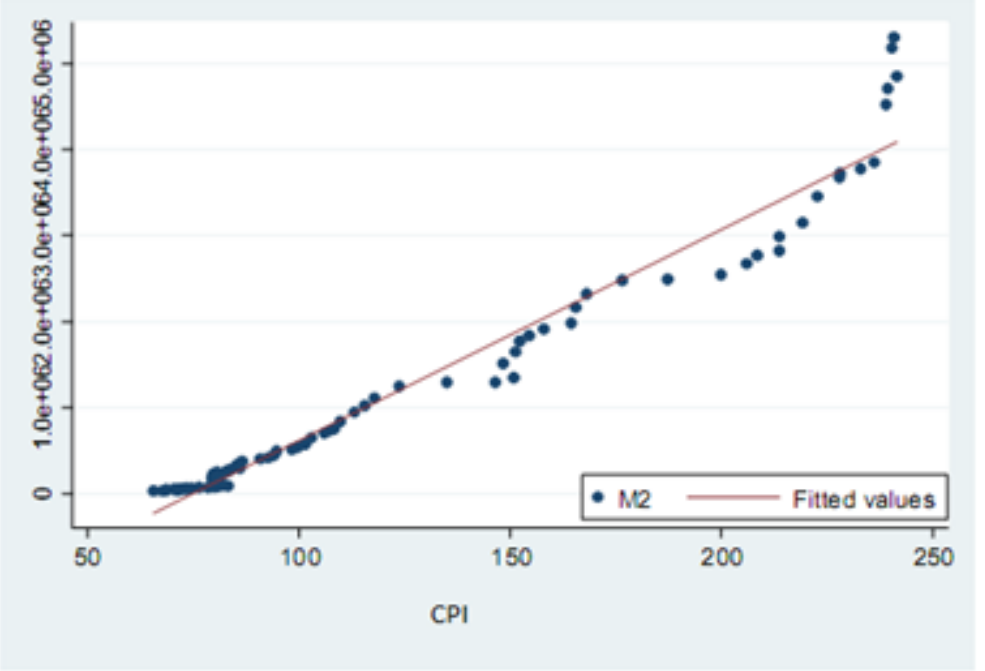

Figure 6: Money supply and CPI regression plot diagram

The evolution of CPI has a rigidly positive relationship with M2 in Vietnam. In reality, the fluctuations in CPI are affected by a plenty of factors, both in long-run and in short-run. However, if the other factors are supposed to change under the impact of certain economic trend, the positive relationship between CPI and M2, hence, is relatively apparent. So, it can be said that the instruments of monetary policy aim to adjust money supply. Once money supply experiences certain fluctuation, it will affect the inflation through four main channels which are interest rate, exchange rate, aggregate credit and asset price. 


\section{Data, Methodology, And Estimated Result}

\subsection{Data}

Table 1. Descriptive data

\begin{tabular}{|l|c|c|c|c|}
\hline Variables & & Mean Value & Min Value & Max Value \\
\hline Domestic CPI & Ln(CPI) & 4.7 & 4.2 & 5.5 \\
\hline Money supply M2 & Ln(M2) & 13.1 & 10.5 & 15.5 \\
\hline Aggregate Credit Balance & Ln(CRD) & 12.9 & 8.2 & 15.2 \\
\hline Average Interest Rate quarterly & LSCV & 12.8 & 5.5 & 28.3 \\
\hline Exchange Rate (VND/USD) & Ln(EX) & 9.7 & 9.3 & 10.0 \\
\hline
\end{tabular}

The data used in this analysis are collected from International Financial Statistics-International Monetary Fund (IFS-IMF), General Statistics Office of Vietnam, etc. The figures are collected from the first quarter of 1995 to the first quarter of 2005 with 81 observations in order to describe the evolution of monetary transmission channels during periods. Inflation is measured by consumer price index (CPI) collected by General Statistics Office; the other variables such as interest rate, average quarter exchange rate, economic credit balance and money supply M2 are collected from IFS-IMF. The descriptive data of variables are clarified in table 1.

\subsection{Methodology}

This analysis uses Structural Equation Model (SEM) to estimate the correlation between monetary policy instrument (M2) and the target of monetary policy (inflation) through the transmission channels. According to Kline (2011), SEM is designed for analyzing these types of indirect transmission effect.

This SEM approach can be described as a simultaneous system of equations as following:

$$
\begin{array}{rc}
\mathrm{LSCV} & =\alpha_{0}+\alpha_{1} M 2+\varepsilon_{1} \\
\mathrm{EX} & =\beta_{0}+\beta_{1} M 2+\varepsilon_{2} \\
\mathrm{CRD} & =\gamma_{0}+\gamma_{1} M 2+\varepsilon_{3} \\
\mathrm{CPI} & =\theta_{0}+\theta_{1}
\end{array}
$$

therein, the variables are defined and explained in table 1 .

This SEM is estimated by MLE (maximum likelihood estimation) approach. The result will indicate level of effect of monetary policy on inflation through transmission channels.

\subsection{Analyzing result SEM}

With the data collected from IMF, General Statistic Office, this paper indicate that money supply in Vietnam affect inflation through three main channels. The estimated result of M2 effect on transmission channel is shown in table 2 .

Table 2. The effect of M2 on transmission channels

\begin{tabular}{lll}
\hline & Coefficient & P-Value \\
\hline M2 on interest rate & $0.0000^{* * *}$ & 0.002 \\
M2 on exchange rate & $0.0019^{* * *}$ & 0.000 \\
M2 on credit & $0.8115^{* * *}$ & 0.000 \\
\hline
\end{tabular}

***: 1\% significant level; **: 5\% significant level; *: 10\%significant level

As being analyzed above, the estimated result shows that M2 does affect interest rate but the impact is very small. This practice is owing to interest rate manipulating mechanism of Central Bank. Although interest rate is adjusted basing on financial market and microeconomic trends, the Central Bank had manipulated ceiling interest rate and established a market interest rate corridor in a certain time period. So, it can be considered that interest rate in Vietnam have just started to adjust according to market signals, or can be said that the money market is not completely competitive.

M2 have the similar impact on exchange rate and credit and these correlations are meaningful at $1 \%$ significant level. Money supply rises at the same time with interest rate, exchange rate and credit but different levels. The increasing speed of credit also affects the encouragement of economic growth or inflation control of Central Bank. Although, credit channel seems to succeed in promoting its role as one of the transmission channels of monetary policy, since 2011, however the effectiveness of this channel has fallen considerably. The results show a pretty high correlation between M2 and credit balance in the economy from 1995 to 2015. Experimental researches under Vietnamese economic background somehow support this practice. Although exchange rates between VND and other strong currencies are announced by Central Bank, this variable still operate under the impact of administrative policy basing on the market evolutions in a certain time period. This fact partly helps to support exchange rate policy in economic growth encouragement and inflation control. 
The next question is to examine the impact of these transmission channels to inflation in Vietnam. The estimated result of SEM is illustrated in table 3.

Table 3. Effect of transmission channel on CPI

\begin{tabular}{lll}
\hline & Coefficient & P-Value \\
\hline Interest rate on CPI & $1.22910 * * *$ & 0.003 \\
Exchange rate on CPI & $0.01124 * * *$ & 0.000 \\
Credit balance on CPI & $0.00002 * * *$ & 0.000 \\
\hline
\end{tabular}

***: 1\% significant level; **: 5\% significant level; *: 10\%significant level

The result shows that interest rate, exchange rate and credit balance all the three channels have a positive effect on CPI at $1 \%$ significant level. Interest rate channel has a relatively strong impact and positively correlates with CPI. This means, monetary policy in Vietnam being operated with a view to controlling inflation is implemented mainly through interest rate channel and exchange rate channel; however the reality of using these tools to attain desire target has been slow down in Vietnam in the past few years. Exchange rate channel has a certain impact on inflation in Vietnam, depending on time period; this level of impact can be really strong or really weak. The practice of maintaining nominal exchange rate at an fluctuate level is a great effort of Central Bank to stabilize money market and the value of Vietnamese currency, however inflation in Vietnam is still high and not stable. Therefore, exchange rate policy during the last time has a tendency to use stability and flexibility as the principles. This activity has had a really positive influence in the operating system of foreign invested enterprises.

In terms of the credit transmission channel, although this is considered as an important transmission channel from monetary policy instruments to inflation in Vietnam and have a positive relation with inflation, the level of transmitting seems to be relatively low at this moment. With the level of money supply and credit development as nowadays, money in general no longer put the same pressure on inflation as before. This means interest rate and exchange rate can be considered as the two main channels and solutions of monetary policy instrument to help control inflation at a desire level of Central Bank.

\section{Conclusion}

This paper mentions about the relationship between money supply and inflation in Vietnam. Basing on the transmission channel operating principle, SEM is used to describe the chain of sequences from money supply to transmission channels and from transmission channels to inflation. Data are collected from 1995 to 2015 to indicate that monetary policy instruments are having a positive impact on inflation in Vietnam especially operating through interest rate channel and exchange rate channel.

\section{References}

Camen,U. (2006), 'Monetary Policy in Vietnam: The Case of a Transition Country', BIS Working Paper No. 31. Bank for International Settlement, Basel.

IMF (2003), Vietnam: Statistical Appendix, IMF Country Report No. 03/382, International Monetary Fund.

IMF (2006), Vietnam: Statistical Appendix, IMF Country Report No. 06/52, International Monetary Fund;

Kline, R.B. (2011), Principles and practice of structural equation modeling, 3rd ed, New York: The Guilford Press.

Lê Việt Hùng \& W. Pfau (2008), VAR Analysis of the Monetary Transmission Mechanism in Vietnam, http://ssrn.com/abstract=1257854.

Miller, R. \& D. Vanhoose (2004), Money Banking and Financial market, Thomson SouthWestern Press

Mishkin, F.S (2004), 'The Economics of Money, Banking, and Financial Markets', Columbia University.

Nguyễn Thùy Vinh \& S. Fujita (2007), 'The Impact of Real Exchange Rate on Output and Inflation in Vietnam: AVAR Approach', Discussion Paper No. 0625.

Phạm Đức Kỳ (2015), Co sở lý thuyết của mô hình mạng (SEM), http://www.mba15.com/view_news.php?id=774 www.mba-15.com

Phạm Thế Anh (2009), Xác định các nhân tố quyết định lạm phát Việt Nam, Tạp chí Kinh tế và phát triển, số 150 , http:ktpt.edu.vn/website/magazine2.aspx."

Trương Văn Phước \& Chu Hoàng Long (2005), 'Chỉ số giá tiêu dùng Việt Nam và các yếu tố tác động: Phương pháptiếp cận định lượng', Thông tin Khoa học Thống kê, số 4/2005.

UNDP (2008), 'Food Inflation in Vietnam: Analysis of Trends and Policy Implications', Research Paper. 